\title{
Association between the use of statins and periodontal status: a review
}

\author{
David R. Rosenberg ${ }^{1 *}$, María Paz Vega ${ }^{2}$, Alejandra Chaparro², Jeremy R. Kernitsky², \\ Catherine X. Andrade ${ }^{2}$, Déborah Violant ${ }^{3}$, José Nart ${ }^{3}$
}

\author{
1. Department of Oral and Maxillofacial Surgery, \\ School of Dentistry, University of the Andes, \\ Santiago, Chile \\ 2. Department of Periodontology, School of \\ Dentistry, University of the Andes, Santiago, Chile \\ 3. Department of Periodontology, Universitat \\ Internacional de Catalunya, Barcelona, Spain
} * Corresponding Author: Dr. David Rosenberg
| Department of Oral and Maxillofacial Surgery, Faculty of Dentistry, Universidad de los Andes, Santiago, Chile; Monseñor Álvaro del Portillo12455, Las Condes - Santiago, Chile | Telephone: +56 9 75171583 | Fax number: +56 224322017 | E-mail: drosenberg@uandes.cl.

Work received on 07/05/2018.

Approved for publication on 05/07/2018

\begin{abstract}
Background: Statins are drugs used for the treatment of dyslipidemia. However, statins have multiple actions, including anti-inflammatory and immunomodulatory effects, as well as the ability to stimulate new bone formation. Such features could be beneficial for periodontal pathology therapy. Methods: A literature review was conducted using filtered electronic databases (Cochrane and Trip) and unfiltered databases (Medline/PubMed, Scielo and Google Scholar). The articles chosen were controlled and randomized clinical trials that performed local delivery of statins to humans and assessed the effects of immunomodulation and bone regeneration on periodontal disease between 2010 and 2017. All of the studies were blind or double-blind and were written in English. Results: The inclusion criteria were applied to a total of 79 identified articles, and 10 studies were ultimately chosen. The results show that an injected dose of statins or the local delivery of atorvastatin (ATV) leads to a significant improvement in clinical and radiographic periodontal parameters. Moreover, rosuvastatin (RSV) induced stronger beneficial effects when administered systemically, whereas ATV and simvastatin (SMV) had better results following topical delivery. Conclusions: Statins can affect periodontal status, increasing the gain in clinical attachment and decreasing gingival bleeding, probing depth and the magnitude of bone defects. For this reason, statins represent an excellent support measure for conventional periodontal therapy. Specifically, positive effects are seen for local delivery of statins as an adjunct treatment to scaling and root planing (SRP) at doses of 1.2 to $2 \%$. Statins could be administered through topical delivery via direct injection in the periodontal pocket or by brushing with medicated dentifrices. More studies with appropriate designs should evaluate the short and long term clinical benefit of statins inpatients with periodontal pathology. These studies should determine the appropriate dose, timing side effects and ideal vehicles for delivery.
\end{abstract}

\section{KEY WORDS}

Statins; Periodontitis; Drug delivery; Drugs and periodontium.

Rev. Clin. Periodoncia Implantol. Rehabil. Oral Vol. 12(1); 41-46, 2019.

\section{INTRODUCTION}

Periodontal disease is highly prevalent. According to a study that estimated the prevalence, severity and extent of periodontitis in the adult population of the United States, more than $47 \%$ of individuals presented with this condition ${ }^{(1)}$. The prevalence of periodontal disease is even higher in Chile. A study conducted in 2010 demonstrated that $93.45 \%$ of individuals between 35 and 44 years of age showed an attachment loss $\geq$ $3 \mathrm{~mm}$ in at least one site. This prevalence is greater in adults between 65 and 74 years of age, who showed an attachment loss $\geq 3 \mathrm{~mm}$ in $97.58 \%$ of $\operatorname{cases}^{(2)}$.

Periodontitis etiology is attributed to specific microorganisms located subgingivally in the gingival sulcus. These microorganisms stimulate an excessive immune-inflammatory response in susceptible hosts. Several proinflammatory molecules and cytokines are synthesized and released during this response, stimulating the destruction of periodontal tissue ${ }^{(3,4)}$.

Statins are inhibitors of 3-hydroxy-3-methylglutaryl CoA reductase and have become one of the most prescribed drugs in the world ${ }^{(5)}$. The prevalence of their use is due to their ability to treat dyslipidemia and to prevent cardiovascular diseases ${ }^{(5,6)}$. Currently, two subtypes of statins are available: natural statins, such as simvastatin (SMV), and synthetic statins, such as atorvastatin (ATV) ${ }^{(7)}$. The properties of statins differ in terms of lipophilicity and hydrophilicity, which are characteristics that affect their ability to pass across cell membranes non-selectively via passive diffusion ${ }^{(6)}$. Lipophilic statins, such as simvastatin and atorvastatin, move easily across the cell membrane. In contrast, the transport mechanism of hydrophilic statins, such as rosuvastatin (RSV), specifically facilitate the entry into hepatic cells ${ }^{(6)}$.

In addition to their primary hypolipidemic action, the following pleiotropic properties are known, which are independent of the cholesterol-lowering action $^{(5)}$ : 1) anti-inflammatory and immunomodulatory, 2) antithrombotic and antiproliferative, and 3) decrease of endothelial dysfunction, oxidative stress, etc. ${ }^{(5,8,9)}$ As statins inhibit the activation of inflammatory response mediators, such as interleukin $1 \beta$ (IL-1 $\beta$ ), interleukin 6 (IL-6), and tumor necrosis factor (TNF- $\alpha$ ), it has been suggested to use these drugs to treat different inflammatory and autoimmune diseases ${ }^{(5)}$. Statins decrease the levels of metalloproteinases (MMPs) $1 / 2 / 8 / 9^{(10)}$ and the inducible nitric oxide synthase (iNOS) enzyme ${ }^{(11)}$. All of these actions are attributed to the capacity of statins to modulate signal transduction pathways that activate proinflammatory transcription factors, such as nuclear factor kappa $\beta$ (NF$\mathrm{K} \beta)^{(10)}$. Moreover, statins can promote the differentiation of osteoblasts by stimulating bone morphogenetic protein-2 (BMP-2) $)^{(12)}$ and vascular endothelial growth factor (VEGF), helping to stimulate the formation of bone tissue ${ }^{(13)}$.

Osteoblasts differentiate in response to several factors, including VEGF. When expressed in osteoblasts, VEGF induces alkaline phosphatase activity and improves responsiveness to parathyroid hormone (PTH) (14). On the other hand, BMP-2 is one of the most potent inductors and stimulators of osteoblast differentiation and bone formation. BMP-2 not only stimulates osteoprogenitor cells to differentiate into osteoblasts but also induces non-osteogenic cells to differentiate into osteoblast lineage cells ${ }^{(15)}$. Statins increase the transcription of BMP-2 and VEGF in osteoblasts by inhibiting protein prenylation, thereby promoting bone formation ${ }^{(14)}$

Due to the pleiotropic, non-hypolipidemic effects of statins, these drugs could potentially be used as coadjuvant therapeutic agents for periodontal disease management. By employing either systemic or local delivery systems, recent studies have explored the biological mechanisms that may be involved in the anti-inflammatory effects of statins on periodontal tissue $^{(12,13,16)}$. In this way, the conventional periodontal treatment approach 
could be augmented with statins to decrease periodontal inflammation ${ }^{(17)}$ and promote bone tissue formation ${ }^{(6)}$.

In vitro studies performed in human periodontal ligament cells demonstrate that low doses of simvastatin stimulate alkaline phosphatase activity, cell proliferation and osteoblast differentiation, suggesting the sensitivity of connective tissue cells to simvastatin ${ }^{(18)}$. The mechanisms by which statins reduce bone loss can be explained by results demonstrating that the local delivery of simvastatin increases the expression of three osteoinductive growth factors (TGF $\beta 1$, BMP-2, and VEGF). Therefore, statins can promote the formation of new bone ${ }^{(16)}$. Furthermore, other studies have shown that the application of systemic simvastatin or atorvastatin decreases the expression of receptor activator of NF-K $\beta$ (RANK) and the receptor activator of NF-K $\beta$ ligand (RANKL) in conjunction with an increase of osteoprotegerin (OPG) levels ${ }^{(12,19)}$. Balli et al. ${ }^{(13)}$ determined that systemic or local delivery of atorvastatin increases VEGF levels. In addition, statins can help to i) decrease free radical release and oxidative stress; ${ }^{(12,19)}$ ii) lower the expression of MMPs $1 / 8 / 9$, IL-1 $1 \beta$, IL-6, and TNF- $\alpha$; and iii) increase the expression of IL-10 ${ }^{(12,20)}$.

The aim of this review is to evaluate the scientific evidence, and quality thereof, regarding the local delivery of statins, particularly simvastatin, atorvastatin and rosuvastatin, with a focus on how they could complement conventional periodontal therapy.

\section{MATERIAL AND METHODS}

The literature search was conducted using filtered electronic databases (Cochrane and Meta-search (Trip)), and unfiltered databases (Medline/ PubMed, Scielo and Google Scholar).

In addition, a manual review was performed of the "Journal of Periodontology", the "Journal of Clinical Periodontology" and "Periodontology 2000", as well as the references mentioned in the selected articles.

The following combinations of Boolean connectors with MeSh terms were used for the electronic search: (statins OR simvastatin OR atorvastatin OR rosuvastatin) AND (periodontitis OR "periodontal disease" OR "periodontal therapy"). Because the search results contained articles that assessed the use of statins in apical periodontitis, the Boolean term NOT was used to exclude such studies. The articles that were obtained as full text in the journals and databases subscribed to by the Library of Universidad de los Andes were compiled. Then, the following inclusion criteria were considered: i) the article was written in English between 2010 and 2017 ; ii) the study described a controlled and randomized clinical trial that was blinded or double-blinded; and iii) the study administered statins via local delivery as an adjunct to scaling and root planning (SRP) in patients with chronic periodontitis who were healthy, smokers or diabetic. Studies combining statins with other bone regeneration techniques were excluded. The articles written in Chinese or other languages were excluded from this review. In the first search, 79 articles were found; 60 articles were excluded due to title selection, then 8 were excluded due to abstract, and finally 1 was excluded after fully reviewing the article. Moreover, 10 were ultimately chosen after applying the inclusion criteria.

\section{RESULTS}

Recently, several randomized clinical trials have been published that study the effect of statins in patients with chronic periodontitis ${ }^{(3,21-29)}$. In general, these studies have demonstrated the effectiveness of topical delivery by injection within periodontal pockets of 3 classes of statins: SMV, ATV and RSV. These statins are generally administered at doses of $1.2 \%$. Only ATV was delivered at a higher concentration (2\%), using a dentifrice as an adjunct treatment to SRP at the same time as the intervention. The main results of these studies are discussed below.

Pradeep \& Thorat ${ }^{(3)}$ studied the local delivery of SMV in 60 generally healthy patients between 25 and 45 years of age with chronic periodontitis. The patients were randomly allocated into two treatment groups, and SRP was performed for both groups. Group 1 was then treated with a placebo gel, while group 2 was treated with $0.1 \mathrm{ml}$ of $1.2 \%$ SMV gel $(1.2 \mathrm{mg} / 0.1$ $\mathrm{ml}$ ) delivered into the periodontal pockets (one site per subject) using a syringe with a blunt cannula. The clinical parameters were measured at baseline and at 1, 2, 4 and 6 months. The radiographic evaluation of intrabony defects was performed at baseline and at 6 months after the intervention using a standardized digital radiograph with individually customized bite blocks and a parallel-angle technique. In addition, gingival crevicular fluid (GCF) samples were collected from drug-delivery sites in 6 randomly selected patients from group 2 (Table 1). The results showed a significant improvement in clinical parameters (modified sulcus bleeding index (mSBI), probing depth (PD) and clinical attachment level (CAL)) 6 months after treatment in both groups $(p=0.001)$. The $\mathrm{mSBI}$ decreased by $2.32 \pm 0.80$ points in group 2 , whereas this decrease was $0.50 \pm 0.68$ points for group 1. The decrease in PD was $1.20 \pm 1.24 \mathrm{~mm}$ and 4.26 $\pm 1.59 \mathrm{~mm}$ in groups 1 and 2, respectively. In addition, a $4.36 \pm 1.92$ $\mathrm{mm}$ increase in CAL was observed in the group treated with SMV versus $1.63 \pm 1.99 \mathrm{~mm}$ in the placebo group. The intrabony defect showed a significantly greater decrease in size $(p<0.001)$ in the SMV group $(1.41 \pm$ $0.74 \mathrm{~mm}$ or $32.54 \%)$ compared to the placebo group $(0.09 \pm 0.58 \mathrm{~mm}$ or $2.16 \%)$. Moreover, it was established that the SMV concentration in GCF reached it maximum level 2 hours after application $(11.43 \pm 0.027 \mu \mathrm{g} /$ $\mathrm{ml})$, but SMV remained for 30 days after application $(0.22 \pm 0.19 \mu \mathrm{g} / \mathrm{ml})^{(3)}$.

Rath et al. ${ }^{(21)}$ analyzed the effect of subgingivally delivered $1.2 \%$ SMV in a group of generally healthy patients with chronic periodontitis ${ }^{(21)}$. After SRP, the patients were divided into 2 treatment groups: 30 patients were allocated into the placebo group, and 30 were treated with $0.1 \mathrm{ml}$ SMV gel at a concentration of $1.2 \%(1.2 \mathrm{mg} / 0.1 \mathrm{ml})$. The clinical periodontal parameters were recorded at baseline (before SRP) and at 60,90 and 180 days. The assessment of the intrabony defects was performed radiographically at baseline and at 180 days. In addition, IL-6 levels were analyzed by RT-PCR using cells obtained from the gingival sulcus at baseline and after 90 days (Table 1). The results are consistent with SMV improving clinical and radiographic parameters. The $\mathrm{mSBI}$ decreased significantly by $2.5 \pm 0.6$ ( $p<0.05) 180$ days after SMV treatment. The probing depth was significantly reduced by $4 \mathrm{~mm}(p<0.05)$ in the SMV treated group compared with the placebo group. However, no significant difference was found in the CAL gain between the groups. The intrabony defect showed a significantly greater improvement in the SMV group at 180 days, decreasing by $0.57 \mathrm{~mm}(p<0.02)$. In addition, the results showed a significant decrease in IL-6 levels 90 days after drug application $(p=0.0001)^{(21)}$.

Pradeep et al. (22) evaluated the efficacy of subgingivally delivered $1.2 \%$ ATV gel as an adjunct to SRP for the treatment of intrabony defects (Table 1). The $\mathrm{mSBI}$ showed a significant reduction $(p<0.05)$ in the group treated with ATV at 3,6 and 9 months. Furthermore, the results indicated that ATV significantly decreased the PD and improved the CAL gain at 3,6 and 9 months $(p<0.001)$. The intrabony defect decreased significantly $(p$ $<0.001)$ at both 6 and 9 months in the ATV group $(1.60 \pm 0.24 \mathrm{~mm}$ at 6 months; $1.70 \pm 0.24 \mathrm{~mm}$ at 9 months) compared to the placebo group $(0.13$ $\pm 0.25 \mathrm{~mm}$ at 6 months; $0.08 \pm 0.26 \mathrm{~mm}$ at 9 months). In addition, the sites treated with ATV showed a significant vertical radiographic bone defect fill after 6 and 9 months $(34.05 \pm 5.79 \%$ and $35.49 \pm 5.50 \%$, respectively, $p$ $<0.001)$. In this study, the bone fill was slightly greater than that obtained previously by Pradeep et al. $\left(32.54 \%\right.$ at 6 months) ${ }^{(3)}$. Therefore, ATV was slightly more effective than $\mathrm{SMV}^{(22)}$.

The clinical and radiographic (bone fill) effect of locally delivered $1.2 \%$ SMV as an adjunct to SRP for treating grade II vestibular furcation defects in mandibular molars was studied by Pradeep et al.(23) In addition to the conventional clinical measurements, the relative vertical attachment level (RVAL) was considered, which was determined by measuring between the LAC and the base of the periodontal pocket, as was the relative horizontal attachment level (RHAL), which was calculated using a Nabers probe. The radiographic evaluation of intrabony defects was performed with a computer-aided program by measuring the distance between the furcation fornix and the base of the defect (Table 1). A significant decrease $(p<0.05)$ in bleeding on probing (BOP) was found in the SMV-treated group at 6 months. The mean PD decrease at 6 months was $1.30 \pm 1.0$ $\mathrm{mm}$ and $4.05 \pm 1.31 \mathrm{~mm}$ for the control and SMV groups, respectively ( $p$ $=0.001)$. A significant increase $(p=0.001)$ in mean RVAL and RHAL in the SMV group was observed. Furthermore, the mean percentage of the bone fill in the SMV group was significantly higher $(25.16 \%)$ than that in the control group $(1.54 \%) 6$ months after treatment $(p=0.001)$.

Rosenberg et al. ${ }^{(24)}$ used a new method for locally delivering statins. Specifically, a dentifrice medicated with $2 \mathrm{mg}$ of ATV or a placebo dentifrice was used to complement non-surgical periodontal treatment ${ }^{(24)}$. Twicedaily teeth brushing for one month was prescribed to both groups (Table 1). The treatment efficacy was assessed by periodontal measurements obtained at the beginning of the study and at 1 month post-therapy. Significant clinical improvements were obtained in the total inflamed periodontal area $(p=0.01)$, mean PD $(p=0.02)$, percentage of sites with PD $\geq 5 \mathrm{~mm}(p=0.002)$, mean CAL $(p=0.001)$, percentage of sites with CAL $\geq 5 \mathrm{~mm}(p=0.01)$, BOP $(p<0.001)$ and gingival index $(p=0.03)$ in the ATV group ${ }^{(24)}$.

Pradeep et al. ${ }^{(25)}$ analyzed the effect of RSV (Table 1). At 6 months after treatment, the RSV-treated group showed a significant improvement $(p=$ 0.000 ) in the $\mathrm{mSBI}$, with a decrease in PD and a gain in CAL. Furthermore, a larger decrease in the mean intrabony defect $(p=0.000)$ was observed ${ }^{(25)}$. Complementing this research, Pradeep et al. ${ }^{(26)}$ compared the efficacy of local delivery of $1.2 \mathrm{mg}$ of ATV, RSV or placebo gels for the treatment of intrabony defects in patients with chronic periodontitis. A re-application of the gels was performed after 6 months to increase the bioavailability of the drug at the site. The mean reductions in the $\mathrm{mSBI}$ and PD, the gain in 
Table 1. Methodology of studies regarding locally delivered statins in humans.

\begin{tabular}{|c|c|c|c|c|c|c|c|}
\hline Author & $\stackrel{\mathrm{N}}{\text { Patients }}$ & $\begin{array}{c}\text { Type of Statins/ } \\
\text { Dose }\end{array}$ & $\begin{array}{l}\text { Delivery } \\
\text { form }\end{array}$ & Inclusion & Exclusion & Clinical variables & $\begin{array}{c}\text { Radiographic } \\
\text { variables }\end{array}$ \\
\hline $\begin{array}{l}\text { Rath et al. } \\
(2012)^{(21)}\end{array}$ & $\begin{array}{c}60 \\
25-45 \\
\text { years }\end{array}$ & $\begin{array}{c}\mathrm{SMV} \\
1.2 \mathrm{mg} / 0.1 \mathrm{ml} \\
\text { in methylcellulose } \\
\text { gel }\end{array}$ & $\begin{array}{l}\text { Only one } \\
\text { subgingival } \\
\text { injection with } \\
\text { a syringe } \\
\text { with a blunt } \\
\text { cannula } \\
\text { (one site per } \\
\text { subject) }\end{array}$ & $\begin{array}{l}\text { Generally healthy } \\
\text { Generalized chronic } \\
\text { periodontitis PD > 5 } \\
\text { mm and radiographic } \\
\text { evidence of vertical } \\
\text { bone loss of } 3 \mathrm{~mm} \text { in } \\
\text { at least } 1 \text { site.. } \\
\text { Capacity to maintain } \\
\text { optimal oral hygiene } \\
\text { after the initial } \\
\text { treatment phase. }\end{array}$ & $\begin{array}{c}\text { Allergy to SMV. } \\
\text { Systemic treatment with } \\
\text { statins. } \\
\text { Aggressive periodontitis. } \\
\text { Smoking. } \\
\text { History of antibiotic or } \\
\text { periodontal therapy in } \\
\text { the last } 6 \text { months. }\end{array}$ & $\begin{array}{c}\text { mSBI } \\
\text { Plaque index (PI) } \\
\text { PD } \\
\text { CAL } \\
\text { Recorded at the } \\
\text { baseline (before the } \\
\text { SRP) and at } 60,90 \\
\text { and } 180 \text { days. } \\
\text { IL-6-mRNA was } \\
\text { analyzed at the } \\
\text { baseline and at } 90 \\
\text { days by PCR }\end{array}$ & $\begin{array}{l}\text { Bone fill (standardized } \\
\text { digital radiograph } \\
\text { with individually } \\
\text { customized bite blocks } \\
\text { and a parallel-angle } \\
\text { technique). Intrabony } \\
\text { defects measured } \\
\text { by software (vertical } \\
\text { distance between the } \\
\text { alveolar bone crest and } \\
\text { the base of the defect) } \\
\text { at baseline and at } 180 \\
\text { days }\end{array}$ \\
\hline $\begin{array}{l}\text { Pradeep } \\
\text { et al. } \\
(2012)^{(22)}\end{array}$ & $\begin{array}{l}60 \\
30-50 \\
\text { years }\end{array}$ & $\begin{array}{c}\text { ATV } 1.2 \\
\mathrm{mg} / 0.1 \mathrm{ml} \text { in } \\
\text { methylcellulose } \\
\text { gel }\end{array}$ & $\begin{array}{l}\text { Only one } \\
\text { subgingival } \\
\text { injection } \\
\text { with a } \\
\text { syringe } \\
\text { with a blunt } \\
\text { cannula } \\
\text { (one site } \\
\text { per subject) }\end{array}$ & $\begin{array}{l}\text { Generally healthy. } \\
\text { Severe chronic } \\
\text { periodontitis: } P D \geq \\
5 \mathrm{~mm} \text { and CAL } \geq 4 \\
\mathrm{~mm} \text {. Vertical bone } \\
\text { loss } \geq 3 \mathrm{~mm}\end{array}$ & $\begin{array}{c}\text { Periodontal or } \\
\text { antibiotic treatment } \\
\text { in the last } 6 \text { months. } \\
\text { Allergy to ATV/statins. } \\
\text { Therapy with systemic } \\
\text { statins. Aggressive } \\
\text { periodontitis, smoking, } \\
\text { alcoholism,DM, } \\
\text { immunosuppression, } \\
\text { pregnancy or } \\
\text { breastfeeding. }\end{array}$ & $\begin{array}{l}\mathrm{mSBl} \text { and } \mathrm{PI} \text { for } \\
\text { full mouth and } \\
\text { specific sites. PD. } \\
\text { CAL. Recorded at } \\
\text { baseline (before the } \\
\text { SRP) and at } 3,6 \\
\text { and } 9 \text { months. }\end{array}$ & $\begin{array}{c}\text { Bone fill } \\
\text { (standardized } \\
\text { digital radiograph } \\
\text { with individually } \\
\text { customized bite } \\
\text { blocks and a parallel- } \\
\text { angle technique). } \\
\text { Intrabony defects } \\
\text { measured by } \\
\text { software (vertical } \\
\text { distance between the } \\
\text { alveolar bone crest } \\
\text { and the base of the } \\
\text { defect) at baseline } \\
\text { and } 6 \text { and } 9 \text { months }\end{array}$ \\
\hline $\begin{array}{l}\text { Pradeep } \\
\text { et al. } \\
(2012)^{(23)}\end{array}$ & $\begin{array}{c}66 \\
30-50 \\
\text { years }\end{array}$ & $\begin{array}{c}\text { SMV } 1.2 \\
\mathrm{mg} / 0.1 \mathrm{ml} \text { in } \\
\text { methylcellulose } \\
\text { gel }\end{array}$ & $\begin{array}{l}\text { Only one } \\
\text { injection at } \\
\text { furcation } \\
\text { sites with } \\
\text { a syringe } \\
\text { with a blunt } \\
\text { cannula }\end{array}$ & $\begin{array}{l}\text { Chronic } \\
\text { periodontitis and } \\
\text { grade II vestibular } \\
\text { furcation defects } \\
\text { in first and second } \\
\text { vital mandibular } \\
\text { molars, with } \\
\text { radiolucent image } \\
\text { in the zone of } \\
\text { the furcation in } \\
\text { the periapical } \\
\text { radiograph. PD of } \\
3 \mathrm{~mm} \text {. }\end{array}$ & $\begin{array}{c}\text { Periodontal or } \\
\text { antibiotic treatment } \\
\text { in the last } 6 \text { months. } \\
\text { Known systemic } \\
\text { disease. Allergy } \\
\text { to SMV. Therapy } \\
\text { with systemic } \\
\text { statins. Aggressive } \\
\text { periodontitis, smoking, } \\
\text { alcoholism. DM, } \\
\text { immunosuppression, } \\
\text { pregnancy or } \\
\text { breastfeeding. } \\
\text { Pieces with } \\
\text { gingival recession, } \\
\text { endodontically treated, } \\
\text { grade III furcation and } \\
\text { grade } 2 \text { mobility }\end{array}$ & $\begin{array}{l}\text { mSBI. PI for full } \\
\text { mouth and specific } \\
\text { site before the } \\
\text { SRP. PD. Relative } \\
\text { vertical attachment } \\
\text { level (RVAL) and } \\
\text { relative horizontal } \\
\text { attachment level } \\
\text { (RHAL). Considered } \\
\text { at baseline (after } \\
\text { the SRP) and at } 3 \\
\text { and } 6 \text { months. }\end{array}$ & $\begin{array}{c}\text { Bone fill } \\
\text { (standardized } \\
\text { digital radiograph } \\
\text { with individually } \\
\text { customized bite } \\
\text { blocks and a parallel- } \\
\text { angle technique). } \\
\text { Intrabony defects } \\
\text { measured by } \\
\text { software (distance } \\
\text { between the furcation } \\
\text { fornix and the base } \\
\text { of the defect) at } \\
\text { baseline and at } 6 \\
\text { months. }\end{array}$ \\
\hline
\end{tabular}

\begin{tabular}{|c|c|c|c|c|c|c|}
\hline Author & N Patients & $\begin{array}{c}\text { Type of Statins/ } \\
\text { Dose }\end{array}$ & $\begin{array}{l}\text { Delivery } \\
\text { form }\end{array}$ & Inclusion & Exclusion & Clinical variables \\
\hline $\begin{array}{l}\text { Rosenberg } \\
\text { et al. (2015) } \\
(24)\end{array}$ & $\begin{array}{c}3630-58 \\
\text { years }\end{array}$ & $\begin{array}{c}2 \mathrm{mg} \text { of ATV with } \\
0.1 \mathrm{ml} \text { of fluoride } \\
\text { dentifrice. }\end{array}$ & $\begin{array}{l}\text { Six syringes } \\
\text { of } 5 \mathrm{ml} \text { for } \\
\text { one month }\end{array}$ & $\begin{array}{c}30 \text { to } 60 \text { years of age. At } \\
\text { least } 14 \text { teeth (excluding } \\
\text { third molars). Chronic } \\
\text { periodontitis (Page \& Eke } \\
\text { classification). Controlled } \\
\text { diabetes (confirmed by } \\
\text { laboratory tests and } \\
\text { consultation with treating } \\
\text { physician). }\end{array}$ & $\begin{array}{l}\text { Inability to comply with the } \\
\text { study protocol. Therapy with } \\
\text { antibiotics or non-steroidal } \\
\text { anti-inflammatory drugs in } \\
\text { the last } 2 \text { months. Use of } \\
\text { calcium channel blockers, } \\
\text { phenytoin, cyclosporine or } \\
\text { any associated drug that } \\
\text { might affect the gingival } \\
\text { tissue. Periodontal treatment } \\
\text { during the last } 12 \text { months. } \\
\text { Autoimmune disorders (self- } \\
\text { reported). Uncontrolled or } \\
\text { poorly controlled diabetes. } \\
\text { Systemic treatment with } \\
\text { statins. Patients who required } \\
\text { antibiotic prophylaxis prior } \\
\text { to the periodontal treatment } \\
\text { or NSAIDs for the pain after } \\
\text { periodontal treatment. }\end{array}$ & $\begin{array}{l}\text { PISA (at baseline). Mean } \\
\text { PD. Percentage of sites } \\
\text { with PD of } 0 \text { to } 2 \mathrm{~mm} \text {. } \\
\text { Percentage of sites with PD } \\
\text { of } 3 \text { to } 4 \mathrm{~mm} \text {. Percentage } \\
\text { of sites with PD } \geq 5 \mathrm{~mm} \text {. } \\
\text { Mean CAL. Percentage } \\
\text { with sites with CAL of } 0 \text { to } \\
2 \mathrm{~mm} \text {. Percentage of sites } \\
\text { with CAL of } 3 \text { to } 4 \mathrm{~mm} \text {. } \\
\text { Percentage of sites with } \\
\text { CAL } \geq 5 \text { mm. BOP. Gingival } \\
\text { index. Oral hygiene index } \\
\text { at baseline and one month } \\
\text { after therapy. }\end{array}$ \\
\hline
\end{tabular}


Table 1. Methodology of studies regarding locally delivered statins in humans.

\begin{tabular}{|c|c|c|c|c|c|c|c|}
\hline Author & N Patients & $\begin{array}{c}\text { Type of } \\
\text { Statins/Dose }\end{array}$ & Delivery form & Inclusion & Exclusion & Clinical variables & $\begin{array}{l}\text { Radiographic } \\
\text { variables }\end{array}$ \\
\hline $\begin{array}{l}\text { Pradeep et } \\
\text { al }(2015)^{(25)}\end{array}$ & $\begin{array}{c}6525-55 \\
\text { years }\end{array}$ & $\begin{array}{c}1.2 \mathrm{mg} / 0.1 \\
\mathrm{ml} \mathrm{RSV} \text { in } \\
\text { methylcellulose } \\
\text { gel. }\end{array}$ & $\begin{array}{c}\text { Only one } \\
\text { injection in } \\
\text { periodontal } \\
\text { pocket with a } \\
\text { syringe with a } \\
\text { blunt cannula } \\
\text { (one site per } \\
\text { subject) }\end{array}$ & $\begin{array}{c}\text { Generally } \\
\text { healthy. Moderate } \\
\text { periodontitis (PD of } \\
5 \text { to } 6 \mathrm{~mm} \text {, CAL of } \\
4 \text { to } 6 \mathrm{~mm} \text { ). Vertical } \\
\text { bone loss } \geq 3 \mathrm{~mm} \text {. At } \\
\text { least } 20 \text { teeth without } \\
\text { periodontal treatment } \\
\text { in the last } 6 \text { months. } \\
\text { Without antibiotic } \\
\text { therapy. }\end{array}$ & $\begin{array}{l}\text { Treatment with systemic } \\
\text { statins. Known or } \\
\text { suspected allergy to the } \\
\text { RSV group. Another } \\
\text { type of periodontitis. } \\
\text { Smoking, alcoholism, or } \\
\text { immunosuppression. Poor } \\
\text { general health. Pregnancy } \\
\text { or breastfeeding }\end{array}$ & $\begin{array}{c}\text { mSBI. PI for full } \\
\text { mouth and specific } \\
\text { site. PD. CAL. } \\
\text { Metrics recorded at } \\
\text { baseline (before the } \\
\text { SRP) and at } 1,3,4 \\
\text { and } 6 \text { months. }\end{array}$ & $\begin{array}{l}\text { Vertical distance } \\
\text { from the alveolar } \\
\text { bone crest to } \\
\text { the base of the } \\
\text { defect at baseline } \\
\text { and at } 6 \text { months } \\
\text { (digital X-rays) }\end{array}$ \\
\hline $\begin{array}{l}\text { Pradeep et } \\
\text { al. }(2016) \\
(26)\end{array}$ & $\begin{array}{c}9025-45 \\
\text { years }\end{array}$ & $\begin{array}{c}1.2 \mathrm{mg} \text { of } \\
\text { ATV or } 1.2 \\
\mathrm{mg} \text { of RSV } \\
\text { in } 0.1 \mathrm{ml} \text { in } \\
\text { methylcellulose } \\
\text { gel. }\end{array}$ & $\begin{array}{l}\text { Only one } \\
\text { injection of } \\
\text { ATV or RSV } \\
\text { in periodontal } \\
\text { pocket with a } \\
\text { syringe with a } \\
\text { blunt cannula } \\
\text { (one site per } \\
\text { subject) }\end{array}$ & $\begin{array}{l}\text { Chronic periodontitis. } \\
\qquad D \geq 5 \mathrm{~mm} \text {. CAL } \\
\geq 3 \mathrm{~mm} \text {. Angular } \\
\text { bone loss } \geq 3 \mathrm{~mm} \text {. } \\
\text { (periapical X-rays) } \\
\text { Generally healthy. } \\
\text { Without antibiotic or } \\
\text { periodontal treatment } \\
\text { in the last } 6 \text { months. }\end{array}$ & $\begin{array}{l}\text { Aggressive periodontitis. } \\
\text { History of allergy to } \\
\text { statins. Therapy with } \\
\text { statins. Systemic } \\
\text { condition or drugs } \\
\text { that change the } \\
\text { periodontal status. } \\
\text { Immunosuppression, } \\
\text { pregnancy or } \\
\text { breastfeeding. Substance/ } \\
\text { tobacco abuse. }\end{array}$ & $\begin{array}{c}\text { PI for full mouth. } \\
\text { mSBI. PD. CAL. } \\
\text { Recorded at baseline } \\
\text { and } 6 \text { and } 9 \text { months } \\
\text { post-op. }\end{array}$ & $\begin{array}{l}\text { Vertical distance } \\
\text { from the alveolar } \\
\text { bone crest to the } \\
\text { base of the defect } \\
\text { at baseline and at } \\
6 \text { and } 9 \text { months } \\
\text { (digital X-rays) }\end{array}$ \\
\hline
\end{tabular}

the CAL, and the reduction in the intrabony defect depth were significantly higher in the statin group than in the placebo gel group $(p<0.001)$. At the same time, RSV treatment showed a larger beneficial effect than ATV at 6 and 9 months ${ }^{(26)}$. Table 2 shows a comparative analysis of the different clinical and radiographic periodontal parameters based on the use of the three types of statins that were topically delivered at the periodontal level.

Another important point is to determine the efficacy of the local delivery of SMV in patients with additional risk factors for periodontal disease,

Table 2. Comparison of the PD, mSBI and intrabony defect decreases, as well as CAL gain, due to local delivery of SMV, ATV and RSV.

\begin{tabular}{|c|c|c|c|c|c|c|}
\hline Author & Statin & Evaluation & $\mathrm{mSBI}$ & PD & CAL & Intrabony defect \\
\hline $\begin{array}{l}\text { Pradeep \& Thorat } \\
\qquad(2010)^{(3)}\end{array}$ & $1.2 \%$ SMV once & $\begin{array}{l}4 \text { months } \\
6 \text { months }\end{array}$ & $\begin{array}{l}2.35 \\
2.32\end{array}$ & $\begin{array}{l}4.23 \mathrm{~mm} \\
4.26 \mathrm{~mm}\end{array}$ & $\begin{array}{l}3.96 \mathrm{~mm} \\
4.36 \mathrm{~mm}\end{array}$ & $\begin{array}{l}\mathrm{NE} \\
1.4 \mathrm{~mm}\end{array}$ \\
\hline $\begin{array}{l}\text { Rath et al. } \\
(2012)^{(21)}\end{array}$ & $\begin{array}{l}1.2 \% \text { SMV } \\
\text { once }\end{array}$ & $\begin{array}{l}3 \text { months } \\
6 \text { months }\end{array}$ & $\begin{array}{l}2.5 \\
2.5\end{array}$ & $\begin{array}{l}3.1 \mathrm{~mm} \\
4 \mathrm{~mm}\end{array}$ & NS & $\begin{array}{c}\mathrm{NE} \\
0.57 \mathrm{~mm}\end{array}$ \\
\hline $\begin{array}{c}\text { Pradeep et al. } \\
(2012)^{(22)}\end{array}$ & $\begin{array}{l}1.2 \% \text { ATV } \\
\text { once }\end{array}$ & $\begin{array}{l}3 \text { months } \\
6 \text { months } \\
9 \text { months }\end{array}$ & $\begin{array}{l}1.37 \\
1.65 \\
1.63\end{array}$ & $\begin{array}{l}2.2 \mathrm{~mm} \\
3.4 \mathrm{~mm} \\
3.7 \mathrm{~mm}\end{array}$ & $\begin{array}{l}2.7 \mathrm{~mm} \\
4.2 \mathrm{~mm} \\
4.5 \mathrm{~mm}\end{array}$ & $\begin{array}{c}\mathrm{NE} \\
1.6 \mathrm{~mm} \\
1.7 \mathrm{~mm}\end{array}$ \\
\hline $\begin{array}{l}\text { Pradeep et al. } \\
\qquad(2012)^{(23)}\end{array}$ & $\begin{array}{l}1.2 \% \text { SMV } \\
\text { once }\end{array}$ & $\begin{array}{l}3 \text { months } \\
6 \text { months }\end{array}$ & $\begin{array}{c}1.8 \\
2.02\end{array}$ & $\begin{array}{l}3.06 \mathrm{~mm} \\
4.05 \mathrm{~mm}\end{array}$ & $\begin{array}{l}3.7 \mathrm{~mm} \\
4.6 \mathrm{~mm} \\
\text { (RVAL) }\end{array}$ & $\begin{array}{c}\mathrm{NE} \\
1.15 \mathrm{~mm}\end{array}$ \\
\hline $\begin{array}{l}\text { Pradeep et al. } \\
\quad(2015)^{(25)}\end{array}$ & $\begin{array}{l}1.2 \% \text { RSV } \\
\text { once }\end{array}$ & $\begin{array}{l}1 \text { month } \\
3 \text { months } \\
4 \text { months } \\
6 \text { months }\end{array}$ & $\begin{array}{l}2.21 \\
3.02 \\
3.47 \\
3.71\end{array}$ & $\begin{array}{l}3.14 \mathrm{~mm} \\
3.31 \mathrm{~mm} \\
3.68 \mathrm{~mm} \\
4.04 \mathrm{~mm}\end{array}$ & $\begin{array}{c}2.31 \mathrm{~mm} \\
2.92 \mathrm{~mm} \\
3.61 \mathrm{~mm} \\
4.2 \mathrm{~mm}\end{array}$ & $\begin{array}{c}\mathrm{NE} \\
\mathrm{NE} \\
\mathrm{NE} \\
2.23 \mathrm{~mm}\end{array}$ \\
\hline $\begin{array}{l}\text { Pradeep et al. } \\
\quad(2016)^{(26)}\end{array}$ & $\begin{array}{l}1.2 \% \text { ATV } \\
\text { once } \\
\text { RSV } 1.2 \% \\
\text { once }\end{array}$ & $\begin{array}{l}6 \text { months } \\
9 \text { months } \\
6 \text { months } \\
9 \text { months }\end{array}$ & $\begin{array}{l}1.84 \\
0.33 \\
2.05 \\
0.34\end{array}$ & $\begin{array}{l}2.33 \mathrm{~mm} \\
1.03 \mathrm{~mm} \\
3.03 \mathrm{~mm} \\
1.55 \mathrm{~mm}\end{array}$ & $\begin{array}{c}2.33 \mathrm{~mm} \\
1.0 \mathrm{~mm} \\
2.88 \mathrm{~mm} \\
1.40 \mathrm{~mm}\end{array}$ & $\begin{array}{l}2.29 \mathrm{~mm} \\
1.03 \mathrm{~mm} \\
2.83 \mathrm{~mm} \\
1.48 \mathrm{~mm}\end{array}$ \\
\hline
\end{tabular}

such as diabetes or smoking.

Pradeep et al. ${ }^{(27)}$ recruited 38 patients with ages between 30 and 50 years with a diagnosis of type 2 diabetes and chronic periodontitis. After performing SRP, $1.2 \%$ SMV or a placebo gel was subgingivally delivered to multiple posterior sites. The group treated with SMV showed a significantly greater decrease in $\mathrm{mSBI}(\mathrm{p}<0.05)$ and PD compared to the placebo group, as well a significant CAL gain $(p<0.001)$. At 6 and 9 months, the intrabony defect was significantly smaller $(p<0.001)$ in the SMV group (1.38 $\pm 0.73 \mathrm{~mm}$ and $1.62 \pm 0.71 \mathrm{~mm}$, respectively) compared to the nontreated group $(0.19 \pm 0.37 \mathrm{~mm}$ and $0.23 \pm 0.49 \mathrm{~mm}$, respectively), and a significant increase in the bone fill was observed in the SMV group (27.63 \pm $13.14 \%$ and $32.64 \pm 12.90 \%$, respectively) compared to the placebo group $\left(3.40 \pm 8.14 \%\right.$ and $4.22 \pm 9.75 \%$, respectively) $(p<0.001)(\text { Table } 3)^{(27)}$.

The effect of SMV local delivery in 40 smokers aged between 30 and 40 years was evaluated by Rao et al. ${ }^{(28)}$ similarly to previous studies (Table 3). A significant decrease of $\mathrm{mSBI}$ and PD was found in the SMV treated group at 3, 6 and 9 months after the drug delivery. In addition, a significant gain in the CAL $(p<0.001)$ was observed. At 6 and 9 months, assessments of the radiographic parameters in the SMV treated group revealed that the intrabony defect was significantly reduced $(1.17 \pm 0.45 \mathrm{~mm}$ and $1.51 \pm 0.47$ $\mathrm{mm}$, respectively) and a significant vertical defect fill had occurred (24.90 \pm $8.98 \%$ and $32.37 \pm 10.23 \%$, respectively $)(p<0.001)^{(28)}$. Following the same methodology, Kumari et al. ${ }^{(29)}$ administered $1.2 \%$ ATV to 66 smokers (Table 3 ) and obtained a significant improvement in several clinical parameters, such as mSBI, PD and CAL ( $p<0.05)$. Furthermore, an intrabony defect reduction of $1.44 \pm 0.41 \mathrm{~mm}$ and $1.53 \pm 0.40 \mathrm{~mm}$ was observed at 6 and 9 months, respectively, in the ATV group, while the placebo group gained $0.14 \pm 0.09 \mathrm{~mm}$ and $0.15 \pm 0.13 \mathrm{~mm}$, respectively $(p<0.001)^{(29)}$. Table 4 shows the results of statin delivery in patients with risk factors for periodontal disease, showing that the improvement in clinical and radiographic parameters is smaller than the improvement found in patients without associated risk factors. 
Table 3. Methodology of studies about local delivery of statins in patients with risk factors for periodontitis.

\begin{tabular}{|c|c|c|c|c|c|c|c|}
\hline Author & N Patients & $\begin{array}{c}\text { Type of } \\
\text { Statins/Dose }\end{array}$ & Delivery form & Inclusion & Exclusion & Clinical variables & $\begin{array}{c}\text { Radiographic } \\
\text { variables }\end{array}$ \\
\hline $\begin{array}{l}\text { Rao et al. } \\
(2013)^{(28)}\end{array}$ & $\begin{array}{c}4030-50 \\
\text { years }\end{array}$ & $\begin{array}{c}1.2 \mathrm{mg} / 0.1 \\
\mathrm{ml} \mathrm{SMV} \mathrm{in} \\
\text { methylcellulose } \\
\text { gel }\end{array}$ & $\begin{array}{l}\text { Only one } \\
\text { subgingival } \\
\text { injection with a } \\
\text { syringe with a } \\
\text { blunt cannula. } \\
\text { Multiple sites } \\
\text { per subject } \\
\text { (posterior } \\
\text { pieces) }\end{array}$ & $\begin{array}{c}\text { Generally healthy. } \\
\text { Severe chronic } \\
\text { periodontitis: } \mathrm{PD} \geq 5 \\
\mathrm{~mm}, \mathrm{CAL} \geq 4 \mathrm{~mm} \text { and } \\
\text { vertical bone loss } \geq \\
3 \mathrm{~mm} \text {. Smoking ( } 10 \\
\text { cigarettes/day for at } \\
\text { least } 5 \text { years) }\end{array}$ & $\begin{array}{l}\text { Periodontal or antibiotic } \\
\text { treatment within the last } \\
6 \text { months. Ex-smokers } \\
\text { and non-smokers. } \\
\text { Known systemic } \\
\text { disease. Allergy to the } \\
\text { SMV group. Therapy } \\
\text { with systemic statins. } \\
\text { Aggressive periodontitis. } \\
\text { Users of tobacco in } \\
\text { any form other than } \\
\text { cigarettes, alcoholism, } \\
\text { or immunosuppression }\end{array}$ & $\begin{array}{c}\text { mSBI, PI for } \\
\text { full mouth and } \\
\text { specific site, } \\
\text { PD, and CAL at } \\
\text { baseline (before } \\
\text { the SRP) and at } 3 \text {, } \\
6 \text { and } 9 \text { months. }\end{array}$ & $\begin{array}{c}\text { Bone fill } \\
\text { (standardized } \\
\text { digital radiograph } \\
\text { with individually } \\
\text { customized bite } \\
\text { blocks and a parallel- } \\
\text { angle technique). } \\
\text { Intrabony defects } \\
\text { measured by } \\
\text { software (distance } \\
\text { between the alveolar } \\
\text { bone crest and the } \\
\text { base of the defect) at } \\
\text { baseline and at } 6 \text { and } \\
9 \text { months. }\end{array}$ \\
\hline $\begin{array}{l}\text { Pradeep et } \\
\text { al. }(2013)^{(27)}\end{array}$ & $\begin{array}{c}3830-50 \\
\text { years }\end{array}$ & $\begin{array}{c}1.2 \mathrm{mg} / 0.1 \\
\mathrm{ml} \mathrm{SMV} \text { in } \\
\text { methylcellulose } \\
\text { gel }\end{array}$ & $\begin{array}{l}\text { Only one } \\
\text { subgingival } \\
\text { injection with a } \\
\text { syringe with a } \\
\text { blunt cannula. } \\
\text { Multiple sites } \\
\text { per subject } \\
\text { (posterior } \\
\text { pieces) }\end{array}$ & $\begin{array}{l}\text { Well controlled type } \\
2 \text { diabetes (DM). } \\
\text { Chronic periodontitis: } \\
\mathrm{PD} \geq 5 \mathrm{~mm}, \mathrm{CAL} \geq \\
4 \mathrm{~mm} \text { and vertical } \\
\text { bone loss } \geq 3 \mathrm{~mm} \text {. } \\
\text { Minimum of } 20 \text { teeth } \\
\text { in mouth }\end{array}$ & $\begin{array}{l}\text { Periodontal or antibiotic } \\
\text { treatment in the last } \\
6 \text { months. Known } \\
\text { systemic disease. } \\
\text { Allergy to SMV. Therapy } \\
\text { with systemic statins. } \\
\text { Hyperlipidemia or need } \\
\text { for a hypolipidemic diet. } \\
\text { Aggressive periodontitis, } \\
\text { smoking, alcoholism, } \\
\text { immunosuppression, } \\
\text { pregnancy, or } \\
\text { breastfeeding. Pieces } \\
\text { with gingival recession, } \\
\text { furcation defects, } \\
\text { endodontically treated, } \\
\text { or presence of third } \\
\text { molars. }\end{array}$ & $\begin{array}{c}\mathrm{mSBI}, \mathrm{PI} \text { for } \\
\text { full mouth and } \\
\text { specific site, } \\
\mathrm{PD} \text {, and CAL at } \\
\text { baseline (before } \\
\text { the SRP) and at } 3, \\
6 \text { and } 9 \text { months }\end{array}$ & $\begin{array}{c}\text { Bone fill } \\
\text { (standardized } \\
\text { digital radiograph } \\
\text { with individually } \\
\text { customized bite } \\
\text { blocks and a parallel } \\
\text { angle technique). } \\
\text { Intrabony defects } \\
\text { measured by } \\
\text { software (vertical } \\
\text { distance between the } \\
\text { alveolar bone crest } \\
\text { and the base of the } \\
\text { defect) at baseline } \\
\text { and at } 6 \text { months }\end{array}$ \\
\hline $\begin{array}{l}\text { Kumari et } \\
\text { al. }(2016)^{(29)}\end{array}$ & $\begin{array}{c}6630-50 \\
\text { years }\end{array}$ & $\begin{array}{c}1.2 \mathrm{mg} / 0.1 \\
\mathrm{ml} \text { ATV in } \\
\text { methylcellulose } \\
\text { gel }\end{array}$ & $\begin{array}{l}\text { Only one } \\
\text { injection in } \\
\text { periodontal } \\
\text { pocket with a } \\
\text { syringe with a } \\
\text { blunt cannula } \\
\text { (one site per } \\
\text { subject) }\end{array}$ & $\begin{array}{c}\text { Chronic periodontitis. } \\
\text { PD } \geq 5 \mathrm{~mm} \text {. CAL } \\
\geq 4 \mathrm{~mm} \text {. Vertical } \\
\text { bone loss } \geq 3 \mathrm{~mm} \text {. } \\
\text { (Periapical X-ray) } \\
\text { Generally healthy, } \\
\text { without antibiotic } \\
\text { therapy or periodontal } \\
\text { treatment in the last } 6 \\
\text { months. Smoking ( } 10 \\
\text { cigarettes per day for } \\
\text { a minimum period of } \\
5 \text { years). }\end{array}$ & $\begin{array}{l}\text { Ex-smokers and } \\
\text { non-smokers. Users } \\
\text { of tobacco in any way } \\
\text { other than cigarettes. } \\
\text { Known systemic } \\
\text { disease. Known or } \\
\text { suspected allergy to } \\
\text { ATV. Treatment with } \\
\text { systemic statins. } \\
\text { Aggressive periodontitis, } \\
\text { alcoholism, } \\
\text { immunosuppression, } \\
\text { pregnancy, or } \\
\text { breastfeeding. }\end{array}$ & $\begin{array}{l}\text { PI for full mouth } \\
\text { PI for specific } \\
\text { site. mSBI. PD. } \\
\text { CAL. Recorded at } \\
\text { baseline and after } \\
3,6 \text { and } 9 \text { months } \\
\text { postoperative } \\
\text { period. }\end{array}$ & $\begin{array}{c}\text { Vertical distance } \\
\text { between the alveolar } \\
\text { bone crest and the } \\
\text { base of the defect } \\
\text { at baseline and at } 6 \\
\text { and } 9 \text { months (digital } \\
\text { X-rays) }\end{array}$ \\
\hline
\end{tabular}

Table 4. Comparison of the PD, mSBI and intrabony defect decreases, as well as the CAL gain, due to local delivery of SMV, ATV and RSV in smokers and diabetic patients.

\begin{tabular}{|c|c|c|c|c|c|c|}
\hline Author & Statin & Evaluation & $\mathrm{mSBI}$ & PD & CAL & Intrabony defect \\
\hline $\begin{array}{l}\text { Pradeep et al. } \\
\qquad(2013)^{(27)}\end{array}$ & $1.2 \%$ SMV once & $\begin{array}{l}3 \text { months } \\
6 \text { months } \\
9 \text { months }\end{array}$ & $\begin{array}{l}1.43 \\
1.73 \\
1.66\end{array}$ & $\begin{array}{l}2.79 \mathrm{~mm} \\
3.79 \mathrm{~mm} \\
4.03 \mathrm{~mm}\end{array}$ & $\begin{array}{l}2.48 \mathrm{~mm} \\
3.83 \mathrm{~mm} \\
3.97 \mathrm{~mm}\end{array}$ & $\begin{array}{c}\mathrm{NE} \\
1.38 \mathrm{~mm} \\
1.62 \mathrm{~mm}\end{array}$ \\
\hline Rao et al. $(2013)^{(28)}$ & $1.2 \%$ SMV once & $\begin{array}{l}3 \text { months } \\
6 \text { months } \\
9 \text { months }\end{array}$ & $\begin{array}{l}0.93 \\
1.18 \\
0.88\end{array}$ & $\begin{array}{l}2.30 \mathrm{~mm} \\
3.37 \mathrm{~mm} \\
3.83 \mathrm{~mm}\end{array}$ & $\begin{array}{l}2.13 \mathrm{~mm} \\
3.20 \mathrm{~mm} \\
3.63 \mathrm{~mm}\end{array}$ & $\begin{array}{c}\mathrm{NE} \\
1.17 \mathrm{~mm} \\
1.51 \mathrm{~mm}\end{array}$ \\
\hline$\underset{(29)}{\text { Kumari et al. (2016) }}$ & 1.2\% ATV once & $\begin{array}{l}3 \text { months } \\
6 \text { months } \\
9 \text { months }\end{array}$ & $\begin{array}{l}1.14 \\
1.16 \\
1.12\end{array}$ & $\begin{array}{l}1.54 \mathrm{~mm} \\
2.66 \mathrm{~mm} \\
3.84 \mathrm{~mm}\end{array}$ & $\begin{array}{l}2.27 \mathrm{~mm} \\
3.61 \mathrm{~mm} \\
4.06 \mathrm{~mm}\end{array}$ & $\begin{array}{c}\mathrm{NE} \\
1.44 \mathrm{~mm} \\
1.53 \mathrm{~mm}\end{array}$ \\
\hline
\end{tabular}

\section{DISCUSSION}

Because statins have anti-inflammatory and immunomodulatory effects, as well as the ability to promote bone formation, they could be useful adjuvants to conventional periodontal therapy.

Initially, studies that tested statins in this context used two types (SMV and ATV), at a concentration of $1.2 \%$, with the results demonstrating that both statins improve the clinical parameters of bleeding on probing, probing depth and loss of clinical attachment(3,22,23,27,28). However, Rath et al. ${ }^{(21)}$ did not find significant differences in CAL gain ${ }^{(21)}$. Previous studies also demonstrated greater bone fill in regions with periodontitis or furcation defects. The delivery of ATV proved to be slightly more effective than SMV regarding bone fill increases. ATV is a lipophilic statin that appears to have a more potent bone-sparing effect than hydrophilic statins, such as pravastatin ${ }^{(22)}$. Alternatively, Rath et al. ${ }^{(21)}$ demonstrated that 
locally delivered SMV significantly reduced IL-6 levels in the sulcus epithelium ${ }^{(21)}$. Moreover, it was found that the concentration of SMV in the GCF peaks 2 hours after application, although the drug is present for 30 days $^{(3)}$.

Continuing with their research, Pradeep et al. used a new type of statin, RSV, demonstrating positive clinical and radiographic effects on periodontal tissues; notably, these effects were significantly greater than those of ATV ${ }^{(25)}$. This superiority could be explained by a greater anti-inflammatory action of RSV. Specifically, this drug inhibits endothelial cell synthesis of P-selectin. which is produced in response to pro-inflammatory cytokines, such as IL-6 $6^{(26,30)}$. The lack of sustainability in the release of these agents over long periods of time was addressed by Pradeep et al. ${ }^{(26)}$, who performed re-delivery at 6 months and observed even greater clinical benefits ${ }^{(26)}$. However, Rosenberg et al. proposed a novel delivery system through a medicated dentifrice with $2 \%$ ATV. This technique could provide significant benefits given its advantages of easy application and low cost, which would facilitate access to these treatments for much of the population. This system might be used not only as a complement to periodontal therapy but also for the prevention and maintenance of this therapy ${ }^{(24)}$.

The advantages of local drug delivery are obtaining high concentrations at the target site with a lower dose, requiring fewer applications, and achieving high patient acceptability. Compared to systemic regimens, local delivery can offer important benefits in terms of adverse effects and patient adherence ${ }^{(22)}$. To achieve therapeutic effects, topically delivered drugs must have the ability to cross biological membranes. The polarities of the drugs determine their ability to access receptor sites. In this regard, lipophilic statins, such as SMV and ATV, have a greater ability to cross cell membranes by passive diffusion and thereby reach their target ${ }^{(31)}$. In contrast, hydrophilic statins, such as RSV, require specific transporters to enter cells ${ }^{25)}$.

The vehicles used for local delivery of drugs should be biocompatible, have predictable biodegradation kinetics and be easy to fabricate ${ }^{(32)}$. Local drug delivery using a gel allows simple, rapid and generalized application to all affected areas. Moreover, local delivery techniques should provide long bioavailability at sufficient minimum inhibitory concentrations for several days ${ }^{(33)}$.

Lastly, this review described three randomized controlled clinical trials that studied the effect of locally delivered statins on patients with risk factors for periodontal disease. Smoking is the most significant modifiable risk factor, affecting the prevalence and progression of periodontal disease in a dosedependent manner ${ }^{(34)}$. Poorly controlled diabetes mellitus (type I and type II) is the most influential risk factor for the development and progression of periodontitis ${ }^{(34)}$. The results obtained in studies with patients with type II diabetes and smoking show that treatment with $1.2 \%$ SMV or ATV produces an improvement in the clinical and radiographic periodontal parameters. These results demonstrate the anti-inflammatory effects of these statins and their role in bone formation. However, when comparing these results with the those of the first study conducted by Pradeep et al., ${ }^{(3)}$ the effects were less pronounced than those obtained in patients with only chronic periodontitis (i.e., without other risk factors). These differences can be explained by the effect of such risk factors on periodontal disease (Tables 2 and 4 )

\section{CONCLUSION}

Analysis of the available scientific evidence demonstrates that statin administration may represent a new approach and a valuable tool as an adjunct to periodontal therapy. Local delivery proved to be ideal given that it provides high concentrations at the target site and decreases the disadvantages of systemic delivery, such as adverse reactions and low patient compliance. Moreover, with local delivery, effective concentrations are maintained up to 30 days after application. We consider topically delivered statins as an adjunct treatment for the prevention of periodontal disease in high-risk patients. Such a treatment strategy enhances the resolution of periodontitis, reverses the associated defects, and represents a form of periodontal maintenance. However, additional appropriately designed studies are necessary to assess the potential benefits of statins in periodontal therapy and to determine the ideal dose and vehicle for delivery.

\section{CONFLICT OF INTEREST:}

The authors have no conflicts of interest to declare.

\section{References}

1. Eke PI, Dye BA, Wei L, Thornton-Evans GO, Genco RJ. Prevalence of periodontitis in adults in the United States: 2009 and 2010. J Dent Res. 2012;91(10):914-20.

2. Gamonal J, Mendoza C, Espinoza I, Muñoz A, Urzúa I, Aranda W, et al. Clinical attachment loss in Chilean adult population: First Chilean National Dental Examination Survey. J Periodontol. 2010;81(10):1403-10.

3. Pradeep AR, Thorat MS. Clinical effect of subgingivally delivered simvastatin in the treatment of patients with chronic periodontitis: A randomized clinical trial. J Periodontol. 2009;81(2):214-22

4. Carrillo de Albornoz Sainz A, García Kass A, Bascones Martínez A. Papel de la IL-6 y TNFalfa en la enfermedad periodontal. Av Periodoncia Implantol Oral. 2006;18(2):83-9.

5. Ramos-Esquivel A, León-Céspedes C. Efectos no hipolipemiantes de las estatinas. Acta Médica Costarric. 2007;49(4):182-9.

6. Lindy O, Suomalainen K, Mäkelä M, Lindy S. Statin use is associated with fewer periodontal lesions: A retrospective study. BMC Oral Health. 2008;8(1):1.

7. Horiuchi N, Maeda T. Statins and bone metabolism. Oral Dis. 2006;12(2):85-101

8. Mennickent C S, Bravo D M, Calvo M C, Avello L M. Efectos pleiotrópicos de las estatinas. Rev Méd Chile. 2008:136(6):775-82.

9. Gómez-Fernández P. [Statins and beneficial effects]. Med Clin (Barc). 2005;125(15):5789.

10. Paumelle R, Blanquart C, Briand O, Barbier O, Duhem C, Woerly G, et al. Acute antiinflammatory properties of statins involve peroxisome proliferator-activated receptor-a via inhibition of the protein kinase C signaling pathway. Circ Res. 2006;98(3):361-369. 11. Nachtigal P, Kopecky M, Solichova D, Zdansky P, Semecky V. The changes in the endothelial expression of cell adhesion molecules and iNOS in the vessel wall after the shortterm administration of simvastatin in rabbit model of atherosclerosis. J Pharm Pharmacol. 2005;57(2):197-203.

12. Dalcico R, de Menezes AMA, Deocleciano OB, Oriá RB, Vale ML, Ribeiro RA, et al. Protective mechanisms of simvastatin in experimental periodontal disease. J Periodontol. 2012;84(8):1145-57.

13. Balli U, Keles GC, Cetinkaya BO, Mercan U, Ayas B, Erdogan D. Assessment of vascular endothelial growth factor and matrix metalloproteinase- 9 in the periodontium of rats treated with atorvastatin. J Periodontol. 2014;85(1):178-87.

14. Maeda T, Kawane T, Horiuchi N. Statins augment vascular endothelial growth factor expression in osteoblastic cells via inhibition of protein prenylation. Endocrinology. 2003:144(2):681-92.

15. Yamaguchi A, Komori T, Suda T. Regulation of osteoblast differentiation mediated by bone morphogenetic proteins, hedgehogs, and Cbfa1. Endocr Rev. 2000;21(4):393-411.

16. Liu C, Wu Z, Sun H. The Effect of Simvastatin on mRNA expression of transforming growth factor- $\beta 1$, bone morphogenetic protein-2 and vascular endothelial growth factor in tooth extraction socket. Int J Oral Sci. 2009;1(2):90-8.

17. Pinheiro PG. Efeito antiinflamatório da atorvastatina na periodontite induzida por ligadura em ratos. 2009. [cited 2017 Mar 19]; Available from: http://www.repositorio.ufc.br/handle/ riufc/1863.

18. Yazawa H, Zimmermann B, Asami Y, Bernimoulin J-P. Simvastatin promotes cell metabolism, proliferation, and osteoblastic differentiation in human periodontal ligament cells. J Periodontol. 2005;76(2):295-302.
19. de Araújo Júnior RF, Souza TO, de Moura LM, Torres KP, de Souza LB, Alves M do SCF, et al. Atorvastatin decreases bone loss, inflammation and oxidative stress in experimental periodontitis. PloS One. 2013;8(10):e75322.

20. Jin J, Zhang X, Lu Z, Li Y, Lopes-Virella MF, Yu H, et al. Simvastatin inhibits lipopolysaccharide-induced osteoclastogenesis and reduces alveolar bone loss in experimental periodontal disease. J Periodontal Res. 2014:49(4):518-26.

21. Rath A, Mahenra J, Thomas L, Sandhu M, Namasi A, Ramakrishna T. A clinical, radiological and IL-6 evaluation of subgingivally delivered simvastatin in the treatment of chronic periodontitis. Int J Drug Deliv. 2012;4(1):70.

22. Pradeep AR, Kumari M, Rao NS, Martande SS, Naik SB. Clinical efficacy of subgingivally delivered $1.2 \%$ atorvastatin in chronic periodontitis: a randomized controlled clinical trial. $\mathrm{J}$ Periodontol. 2013;84(7):871-9.

23. Pradeep A r., Priyanka N, Kalra N, Naik SB, Singh SP, Martande S. Clinical efficacy of subgingivally delivered $1.2-\mathrm{mg}$ simvastatin in the treatment of individuals with class II furcation defects: A randomized controlled clinical trial. J Periodontol. 2012;83(12):1472-9.

24. Rosenberg DR, Andrade CX, Chaparro AP, Inostroza CM, Ramirez V, Violant D, et al. Short-term effects of $2 \%$ atorvastatin dentifrice as an adjunct to periodontal therapy: a randomized double-masked clinical trial. J Periodontol. 2015;86(5):623-630.

25. Pradeep AR, Karvekar S, Nagpal K, Patnaik K, Guruprasad CN, Kumaraswamy KM Efficacy of locally delivered $1.2 \%$ rosuvastatin gel to non-surgical treatment of patients with chronic periodontitis: a randomized, placebo-controlled clinical trial. J Periodontol. 2015;86(6):738-45.

26. Pradeep Ar., Garg V, Kanoriya D, Singhal S. 1.2\% Rosuvastatin Versus 1.2\% Atorvastatin gel local drug delivery and redelivery in treatment of intrabony defects in chronic periodontitis: A randomized placebo-controlled clinical Trial. J Periodontol. 2016;87(7):756-62.

27. Pradeep A r., Rao NS, Bajaj P, Kumari M. Efficacy of subgingivally delivered simvastatin in the treatment of patients with type 2 diabetes and chronic periodontitis: A randomized double-masked controlled clinical trial. J Periodontol. 2012;84(1):24-31

28. Rao NS, Pradeep AR, Bajaj P, Kumari M, Naik SB. Simvastatin local drug delivery in smokers with chronic periodontitis: a randomized controlled clinical trial. Aust Dent J. 2013;58(2):156-62.

29. Kumari M, Martande SS, Pradeep AR. Subgingivally delivered $1.2 \%$ atorvastatin in the treatment of chronic periodontitis among smokers: a randomized, controlled clinical trial. J Investig Clin Dent. 2017:8(2).

30. Stalker TJ, Lefer AM, Scalia R. A new HMG-CoA reductase inhibitor, rosuvastatin, exerts anti-inflammatory effects on the microvascular endothelium: the role of mevalonic acid. $\mathrm{Br} \mathrm{J}$ Pharmacol. 2001;133(3):406-12.

31. Bracht L, Caparroz-Assef SM, Magon TF dos S, Ritter AMV, Cuman RKN, BersaniAmado CA. Topical anti-inflammatory effect of hypocholesterolaemic drugs. J Pharm Pharmacol. 2011;63(7):971-5

32. Gilding DK, Reed AM. Biodegradable polymers for use in surgery-polyglycolic/poly(actic acid) homo- and copolymers: 1. Polymer. 1979;20(12):1459-64.

33. Elavarasu S, Suthanthiran TK, Naveen D. Statins: A new era in local drug delivery. J Pharm Bioallied Sci. 2012;4(Suppl 2):S248-51.

34. Alvear FE, Vélez ME, Botero L. Factores de riesgo para las enfermedades periodontales. Rev Fac Odontol Univ Antioquia. 2010; 22(1):109-116. 